\title{
Pupils' perceptions of informal learning in school music lessons
}

Professor Susan Hallam, University College London, Institute of Education

20 Bedford Way, London, WC1H OAL

s.hallam@ioe.ac.uk

Dr Andrea Creech, University College London, Institute of Education

20 Bedford Way, London, WC1H OAL

a.creech@ioe.ac.uk

Dr Hilary McQueen, University College London, Institute of Education

20 Bedford Way, London, WC1H OAL

h.mcqueen@ioe.ac.uk

\begin{abstract}
Music education has faced considerable challenges in trying to bridge the gap between music in young people's lives and that taking place in the classroom. The 'Musical Futures' initiative aimed to devise new and imaginative ways of engaging young people, aged 11-19, in music activities through a process of informal learning based initially on popular music. This research aimed to explore pupils' perceptions of the impact of adopting the Musical Futures approach on students' learning and attainment. 671 students completed a questionnaire and 171 participated in focus group interviews to establish their perceptions of informal learning. The findings showed that the adoption of the Musical Futures approach enhanced student interest and confidence and increased their musical skills. Students appreciated the control that they had over their learning but some raised issues about working in groups and the level of support that teachers were able to offer.
\end{abstract}




\section{Introduction}

In the UK, over a considerable period time, there has been concern about the place of music in the secondary school curriculum. Low numbers of students opt to take music at Key Stage 4 (aged 14 to 16) and at Key Stage 5 (aged 16 to 18) compared with other subjects including those in the arts (McQueen \& Hallam, 2010). Despite this, students do not dislike music (Lamont et al., 2003) and enjoy working practically and making music with their friends and peers. Music is perceived to enhance their self-esteem, particularly through performing to others (Ofsted, 2009; Hallam et al., 2009). Students and their teachers indicate that they value the role of music in the curriculum for its musical and extra-musical benefits (Lamont et al., 2003). However, there are differences between schools in the level of up-take at KS4 (Little, 2009). This may be because in some schools music is perceived to lack relevance and links are not always made with music outside school (Bray, 2000; Lamont et al., 2003). Some students perceive that only those with high level instrumental skills will be able to succeed (Lamont et al., 2003; Wright, 2002). This is reinforced by some teachers who do not encourage those without instrumental skills from taking music at KS4 (Ofsted, 2009). Students who have high level instrumental skills and pursue music as an extra-curricular activity may see no need to continue with music at KS4 unless they wish to pursue a career in music (Little, 2009). In addition, music is perceived to have little value for careers in the wider community (Lamont et al., 2003; Hallam et al., 2009) and parents are not always supportive of their children taking it (Button, 2006; Hallam et al., 2009).

The issues raised above are relevant internationally. Many young people do not value music education as highly as other subjects at school, particularly after they make the transition to secondary school (Ghazali \& McPherson, 2009; McPherson, 2007; O’Neill, 2006; Pitts, 2005). Research based on expectancy-value theory (Eccles \& Wigfield, 2002) suggests that motivation depends on beliefs about competence, perceptions of task difficulty, and the perceived value of the subject. In a recent comparative study of eight countries, not including the UK, McPherson and O’Neill (2010) found that there was a decline in value and competence beliefs in music and an 
increase in perceptions of task difficulty as students progressed through school. Females reported higher competence beliefs and values and lower task difficulty ratings for music than males. The only exception to these findings was the data from Brazil.

In the UK, in an attempt to address the challenges of engaging students' interest in school music, the Musical Futures programme has been introduced. This is based on informal learning in the classroom, initially with a focus on popular music. While this represents a change in the UK, such an approach was initiated in Scandinavia some time ago. In the 1960s, the Nordic countries, particularly Sweden, addressed the relevance of school music to students as part of more general education policy which focused on the entitlement of each student to have his or her individual needs and interests recognised in schools. As a consequence, stronger links were made between students' extra-curricular music activities and the activities that they undertook in the classroom. During the 1970s, in Sweden, popular music became part of the compulsory school curriculum. It was typically taught using informal learning processes which reflected those adopted by popular musicians (Karlsen \& Vakeva, 2012). Since the implementation of this curriculum evaluative research has shown that while pupils enjoyed music making in school, they also reported that it was outdated and that many contemporary genres were not included (Skolverket, 2004). As a result, some groups of students' needs were not met and they tended to become disengaged (Bergman, 2009).

In the UK, the adoption of informal learning practices in school music has been more recent than in the Nordic countries. It has largely been implemented through the Musical Futures approach. This was designed to devise new and imaginative ways of engaging young people, aged 11-19, in musical activities, providing all children with opportunities to engage with music that reflected their interests while also empowering them in taking control of their musical learning (Finney \& Philpott, 2010). The approach was launched in 2003 and emerged from the work of Lucy Green who researched how musicians working in popular genres learned through listening and playing by ear 
(Green, 2002; 2008). The original pilot work took place between 2004 and 2006 in three Local Authority Music Services with four key strands emerging. The first strand, Informal Music Learning at Key Stage 3 (aged 11-14) was based on the real-life learning practices and processes of popular musicians, encouraging students to learn alongside friends, using independent, self-directed learning processes with teachers acting as facilitators. The second strand, the Whole Curriculum Approach was focused on Year 8 students (aged 12-13) who had not previously experienced sustained musical engagement and included extra support for the teacher, introducing informal learning processes, making connections with students' musical activities outside school, and involving students in real musical activities. The third strand, Personalising Extra-Curricular Music provided guidance for teachers on how to make extra-curricular activities and curricular work in schools complementary to enhance students' musical progression, while the fourth strand, NUMU (www.numu.org.uk) provided opportunities for students to develop skills in creating music, publishing, marketing and promoting through an interactive website (see Hallam et al., 2008). Following the pilot work a toolkit of teacher resources was published which included a wide range of materials including lesson plans, National Curriculum mapping, video and audio material, case studies and quotes from participants, students and teachers (www.musicalfutures.org). A two-year Continuing Professional Development (CPD) programme was offered and in 2008 a national network of 'Champion Schools' was established (d'Amore, 2014). Since then, the approach has developed as teachers provided feedback with two key areas being identified, informal learning and non-formal learning. The informal learning strand is based on students determining their own targets and learning through self-directed activities starting with familiar music, moving on to other genres and ultimately composition with the teacher modelling, supporting, advising and guiding. Non-formal teaching includes fully inclusive group-based activities in performing, listening, composing and improvising with teachers and students co-constructing content. These developments have led to a new definition of Musical Futures as 'an approach to teaching and learning... a new way of thinking about music-making in schools that brings non-formal teaching 
and informal learning approaches into the more formal context of schools' (Musical Futures, 2014, p 9).

Schools have adopted Musical Futures in different ways. A survey of about 700 teachers adopting or planning to adopt the musical futures approach (Hallam et al., 2008) showed that the majority made use of the informal music learning model, although about a quarter either used or planned to use the Whole Curriculum Approach or NUMU with a smaller number using or planning to use the model for Personalising Extra-Curricular Music. The approaches were most often used with Year 9 groups (aged 13-14), least frequently with year 7 (aged 11-12) and typically over the course of an entire academic year. Those planning to implement Musical Futures believed that adoption of the approach would increase motivation, provide a more stimulating curriculum, raise standards, enhance musical skills, provide professional development, and increase the numbers of students taking the General Certificate of School Education (GCSE) in music. Evaluations of the Musical Futures approach to teaching music, in the UK and internationally, suggest that these expectations were realistic as they showed that student motivation and enthusiasm for music was enhanced (see Benson, 2012; Evans, Beauchamp \& John, 2015; Hallam et al., in press a; Jeanneret, 2010; Jeanneret et al., 2011; John \& Evans, 2013; Ofsted, 2006; O’Neill \& Bespflug, 2011; Younker et al., 2012).

In assessing the impact of any initiative it is important that the views of the students themselves are taken into account. Indeed, there has been increasing recognition that children have rights and are entitled to be involved in decisions and actions that affect them (United Nations, 1989; 2005). There is also considerable evidence that children are capable, competent and active thinkers who are able to express their views coherently (e.g. Clark and Moss 2001). Taking this into account, the current research, based in schools in England, aimed to explore how students involved in Musical Futures perceived its impact on them. The specific research questions were: 
To what extent do students participating in the Musical Futures approach believe that the approach has had an impact on their concentration in music lessons, their learning and attainment, their team working skills, their enthusiasm and interest in music, and their self-beliefs?

To what extent was the Musical Futures approach perceived by students to have benefits in relation to other school subjects?

How did students participating in Musical Futures perceive their teachers and their teaching?

\section{Methods}

\section{Research design}

The research was based in a number of case study Musical Futures champion schools. The research was funded by the Paul Hamlyn Foundation which in turn supported the Musical Futures programme. The choice of champion schools was determined by the funder. A mixed methods approach was adopted with students completing questionnaires followed by focus group interviews with some students. The use of multiple methods has long been recognised as a means of enhancing validity (Bouchard, 1976). Combining methods provides triangulation (Patton, 2001). The qualitative data were collected in order to confirm the findings from the questionnaire and to offer more in depth insights into the perceptions of the students.

\section{The sample completing the questionnaires}

Six case study schools were selected in consultation with the Musical Futures team to represent different types of school and differences in experience with Musical Futures. One additional school was recruited to allow for attrition. Students in this school participated in the questionnaire element of the research only. The schools had different characteristics. They also differed in the way in 
which they were implementing Musical Futures. Table 1 sets out the details of the case study schools at the time of the research.

Table 1: Case study schools

\begin{tabular}{|l|l|l|l|l|l|l|l|}
\hline School & $\begin{array}{l}\text { Specialist } \\
\text { status }\end{array}$ & $\begin{array}{l}\text { Number } \\
\text { on roll }\end{array}$ & Ethnic make up & FSM & EAL & $\begin{array}{l}\text { OFSTED } \\
\text { grade }\end{array}$ & $\begin{array}{l}\text { Music exams } \\
\text { taken in KS4 }\end{array}$ \\
\hline School A & Technology & 1416 & $\begin{array}{l}\text { Mainly White } \\
\text { British }\end{array}$ & Low & Low & Satisfactory & BTEC \\
\hline $\begin{array}{l}\text { School B } \\
\text { Boys school }\end{array}$ & Arts & 1447 & $\begin{array}{l}\text { Over 50\% } \\
\text { black and } \\
\text { minority ethnic } \\
\text { backgrounds }\end{array}$ & High & High & Good & BTEC \\
\hline School C & $\begin{array}{l}\text { Language } \\
\text { and } \\
\text { technology }\end{array}$ & 1790 & $\begin{array}{l}\text { Mainly White } \\
\text { British }\end{array}$ & Low & Low & Outstanding & GCSE \\
\hline School D & Science & 1286 & $\begin{array}{l}\text { Mainly } \\
\text { minority ethnic } \\
\text { backgrounds }\end{array}$ & High & High & Satisfactory & BTEC \\
\hline School E & Science & 1223 & $\begin{array}{l}\text { Mainly White } \\
\text { British }\end{array}$ & Low & Low & Satisfactory & $\begin{array}{l}\text { GCSE } \\
\text { Rockschool }\end{array}$ \\
\hline School F & Visual arts & 956 & $\begin{array}{l}\text { Mainly White } \\
\text { British }\end{array}$ & Low & Low & Outstanding & GCSE \\
\hline School G & Visual arts & 806 & $\begin{array}{l}\text { Mainly White } \\
\text { British }\end{array}$ & Low & Low & Outstanding & GCSE \\
\hline
\end{tabular}

*FSM $=$ free school meals; EAL $=$ English as an additional language

A total of 671 students, including 394 boys and 277 girls, completed the questionnaire.

The number of student responses from each school ranged between 46 and 116. Percentages were calculated for ethnicity and year group. These have been rounded up or down to the nearest whole number and may not add to $100 \%$. The majority of students were white $(74 \%, 445) .12 \%(74)$ were Asian, $8 \%$ (46) were black, 5\% (29) were of mixed race, the remainder being Hispanic, Arabian or Chinese. Most students were British (93\%) although 28 different nationalities were represented. Eleven percent (77) of the sample were in Year 7 (aged 11-12), 49\% (328) in Year 8 (aged 12-13), 34\% (228) in Year 9 (aged 13-14), 5\% (36) in Year 10 (aged 14-15), and .002\% (2) in Year 11 (aged 15-16). Twelve percent of the sample was eligible for free school meals. The students 
represented a wide range of general attainment ranging from SATs level 3 up to a high level 6 $(6.7 \%)$. The greatest proportion $(46 \%)$ was at level 5.

Seventy-two percent (475) of the sample indicated that they could play one or more musical instruments or could sing. Only seven students reported playing more than three instruments. The details of instruments played are set out in Table 2 .

Table 2: Instruments played by the student participants

\begin{tabular}{|l|l|l|l|}
\hline & $\begin{array}{l}\text { Instrument 1 } \\
(\%)\end{array}$ & $\begin{array}{l}\text { Instrument 2 } \\
(\%)\end{array}$ & $\begin{array}{l}\text { Instrument 3 } \\
(\%)\end{array}$ \\
\hline Guitar & 23.2 & 16.7 & 28.2 \\
\hline Piano or keyboard & 26.8 & 36.7 & 15.4 \\
\hline Drums & 15.1 & 14.0 & 10.3 \\
\hline Brass instrument & 2.9 & 4.0 & 5.1 \\
\hline Woodwind instrument & 6.4 & 6.7 & 7.7 \\
\hline String instrument & 2.0 & 2.7 & 7.7 \\
\hline Other percussion & .4 & 1.3 & 2.6 \\
\hline Classical guitar & .2 & & 28.2 \\
\hline Recorder & 1.3 & 5.3 & 15.4 \\
\hline Rapper/MC & .9 & & \\
\hline Steel pans & .2 & & \\
\hline Kazoo & & .7 & \\
\hline Harmonica & & .7 & \\
\hline
\end{tabular}

One hundred and four students in the sample reported participating in a musical group. Twenty three students reported participating in choir (3.4\% of the whole sample), 83 in a wind/concert band (12\%), 10 in an orchestra (1.5\%) and 8 in another kind of ensemble (1\%). Most students only participated in one musical group. Only 18 students participated in more than one group. 


\section{The questionnaire}

The questionnaire had previously been used in research in relation to the Musical Futures programme (see Hallam et al., 2008) where it had been piloted. The statements included in the questionnaire were derived from the existing literature and informal evidence from teachers who had previously adopted the Musical Futures approach. The 2008 research demonstrated that the questionnaire was fit for purpose. In the questionnaire students were asked to rate themselves in terms of their expertise on their first instrument. They were also asked to respond on a five point Likert scale to a series of statements relating to working with friends, teamwork, concentration, achievement, changes in listening, enjoyment of school music, self-beliefs, confidence, and their perceptions of their teachers and their teaching. The Cronbach's Alpha for the scale was .895. The questionnaire took the students about 15 minutes to complete.

\section{The focus group interviews}

Focus group interviews were undertaken with 171 students representing a range of year groups and ability levels. In School , 32 students participated in the focus groups, in School B, 18 (all boys), in School C, 29, School D, 28, School E, 23, and School F, 41. The size of group varied depending on circumstances but was typically between 4 and 6 . The groups included representatives from different year groups and those identified by their teachers as of varying levels of musical expertise (low, moderate, high). The focus group interviews were undertaken within the same time period as the completion of the questionnaires. The focus groups typically lasted for about 45 minutes.

Students were asked in the focus group interviews if Musical Futures had had an impact on their learning and progress, what they had enjoyed, what had been helpful, how different teachers approached teaching, issues about working with other students, and the skills they had developed. 


\section{Procedure}

A member of the research team visited the participant schools for the purposes of administering and collecting questionnaires and undertaking the focus group interviews. Both were undertaken on the same visit.

\section{Ethics}

Ethical guidelines from the British Educational Research Association were followed. Consent was obtained from all participants and their parents prior to the research. They were ensured of anonymity. Confidentiality could not be guaranteed as quotes from interviews were to be used in reporting the findings. Those participating in the focus groups were told that they could withdraw from the process at any time. When completing the questionnaires students were assured that their teachers would not see their responses and that they need not respond if they did not wish to do so.

\section{Data analysis}

The questionnaire data were analysed using the Statistical Package for the Social Sciences (SPSS). Means, percentages and standard deviations were calculated and analysis of variance used to compare the responses of girls and boys and those reporting playing an instrument and those not playing an instrument. The focus group interviews were transcribed in full. The analysis of the qualitative data was designed to triangulate that of the questionnaires and provide more in depth insights giving a more balanced and detailed account (Altrichter et al., 2008). The elements in the questionnaire were used to guide the analysis. Three researchers worked independently in analyzing the data to ensure dependability (Lincoln and Guba, 1985). 


\section{Findings}

The findings are presented in relation to each of the three research questions.

To what extent do students participating in the Musical Futures approach believe that the approach has had an impact on their concentration in music lessons, their learning and attainment, their team working skills, their enthusiasm and interest in music, and their selfbeliefs?

Concentration and focus: Only $44 \%$ of the participants believed that they concentrated better in music lessons than other lessons, although $71 \%$ indicated that music lessons seemed to go more quickly than other lessons (see Table 3). There were no gender differences in response to these statements. However, there were statistically significant differences between those who played one or more instruments and those indicating that they did not play instruments. Those playing instruments responded more positively (see Table 4).

Table 3: Benefits of Musical Futures lessons

\begin{tabular}{|c|c|c|c|c|c|c|c|}
\hline & $\begin{array}{l}\text { Strongly } \\
\text { agree }\end{array}$ & Agree & $\begin{array}{l}\text { Don't } \\
\text { know }\end{array}$ & Disagree & $\begin{array}{l}\text { Strongly } \\
\text { disagree }\end{array}$ & Mean & $\mathrm{SD}$ \\
\hline \multicolumn{8}{|c|}{ Concentration and focus } \\
\hline $\begin{array}{l}\text { I concentrate better in music } \\
\text { lessons than in other lessons }\end{array}$ & $16 \%(104)$ & $28 \%(186)$ & $15 \%(98)$ & $35 \%(229)$ & $7 \%(45)$ & 3.1 & 1.2 \\
\hline $\begin{array}{l}\text { Music lessons seem to go more } \\
\text { quickly than other lessons }\end{array}$ & $33 \%(219)$ & $38 \%(250)$ & $8 \%(51)$ & $16 \%(108)$ & $5 \%(36)$ & 3.8 & 1.2 \\
\hline \multicolumn{8}{|c|}{ Learning and attainment } \\
\hline $\begin{array}{l}\text { The activities we do in music } \\
\text { have helped me to become a } \\
\text { better musician }\end{array}$ & $23 \%(151)$ & $49 \%(327)$ & $12 \%(80)$ & $13 \%(86)$ & $3 \%(23)$ & 3.7 & 1.1 \\
\hline $\begin{array}{l}\text { Music lessons have helped me to } \\
\text { listen to music differently }\end{array}$ & $18 \%(121)$ & $34 \%(224)$ & $12 \%(80)$ & $30 \%(197)$ & $7 \%(44)$ & 3.3 & 1.2 \\
\hline $\begin{array}{l}\text { I have achieved a lot in music } \\
\text { lessons }\end{array}$ & $18 \%(122)$ & $43 \%(287)$ & $\begin{array}{l}17 \% \\
(115)\end{array}$ & $16 \%(109)$ & $5 \%(33)$ & 3.5 & 1.1 \\
\hline \multicolumn{8}{|c|}{ Teamwork } \\
\hline $\begin{array}{l}\text { I think I work better in music } \\
\text { when I work with my friends }\end{array}$ & $48 \%(332)$ & $36 \%(241)$ & $5 \%(37)$ & $8 \%(54)$ & $2 \%(16)$ & 4.3 & 1.0 \\
\hline
\end{tabular}




\begin{tabular}{|c|c|c|c|c|c|c|c|}
\hline $\begin{array}{l}\text { I have learnt how to work in a } \\
\text { group in music lessons }\end{array}$ & $31 \%(209)$ & $51 \%(340)$ & $4 \%(26)$ & $9 \%(59)$ & $5 \%(31)$ & 4.0 & 1.1 \\
\hline $\begin{array}{l}\text { I often help others in music } \\
\text { lessons }\end{array}$ & $13 \%(86)$ & $46 \%(303)$ & $13 \%(83)$ & $22 \%(145)$ & $6 \%(41)$ & 3.4 & 1.1 \\
\hline \multicolumn{8}{|c|}{ Enthusiasm and interest } \\
\hline $\begin{array}{l}\text { I attend music lessons in school } \\
\text { regularly }\end{array}$ & $42 \%(274)$ & $37 \%(242)$ & $5 \%(35)$ & $10 \%(64)$ & $7 \%(44)$ & 4.0 & 1.2 \\
\hline I enjoy music lessons at school & $30 \%(202)$ & $59 \%(393)$ & $2 \%(13)$ & $7 \%(47)$ & $2 \%(15)$ & 4.1 & .9 \\
\hline $\begin{array}{l}\text { I want to do well in music } \\
\text { lessons }\end{array}$ & $41 \%(271)$ & $49 \%(329)$ & $5 \%(37)$ & $4 \%(24)$ & $1 \%(6)$ & 4.3 & .8 \\
\hline \multicolumn{8}{|c|}{ Self-beliefs } \\
\hline $\begin{array}{l}\text { I can usually do things as well as } \\
\text { most other people in music } \\
\text { lessons }\end{array}$ & $19 \%(128)$ & $48 \%(316)$ & $12 \%(82)$ & $\begin{array}{l}16 \% \\
(104)\end{array}$ & $5 \%(34)$ & 3.6 & 1.1 \\
\hline $\begin{array}{l}\text { I feel good about myself most of } \\
\text { the time in music lessons }\end{array}$ & $23 \%(151)$ & $50 \%(332)$ & $11 \%(71)$ & $13 \%(88)$ & $4 \%(27)$ & 3.7 & 1.1 \\
\hline I feel confident in music lessons & $25 \%(168)$ & $48 \%(322)$ & $7 \%(46)$ & $\begin{array}{l}15 \% \\
(102)\end{array}$ & $4 \%(29)$ & 3.7 & 1.1 \\
\hline I have good musical skills & $16 \%(110)$ & $40 \%(265)$ & $\begin{array}{l}16 \% \\
(108)\end{array}$ & $\begin{array}{l}20 \% \\
(134)\end{array}$ & $7 \%(49)$ & 3.4 & 1.2 \\
\hline I think I'm a musical person & $24 \%(159)$ & $31 \%(202)$ & $12 \%(81)$ & $\begin{array}{l}24 \% \\
(156)\end{array}$ & $9 \%(62)$ & 3.4 & 1.3 \\
\hline \multicolumn{8}{|c|}{ Benefits to other subjects } \\
\hline $\begin{array}{l}\text { Doing music lessons has helped } \\
\text { me in other school subjects as } \\
\text { well }\end{array}$ & $9 \%(60)$ & $21 \%(139)$ & $\begin{array}{l}18 \% \\
(123)\end{array}$ & $\begin{array}{l}35 \% \\
(236)\end{array}$ & $16 \%(108)$ & 2.7 & 1.2 \\
\hline $\begin{array}{l}\text { Doing music lessons has helped } \\
\text { me to feel more positive about } \\
\text { school }\end{array}$ & $19 \%(128)$ & $32 \%(215)$ & $14 \%(95)$ & $\begin{array}{l}22 \% \\
(151)\end{array}$ & $12 \%(81)$ & 3.2 & 1.3 \\
\hline \multicolumn{8}{|c|}{ Perceptions of teachers } \\
\hline $\begin{array}{l}\text { My teacher values the music I } \\
\text { am interested in }\end{array}$ & $14 \%(97)$ & $29 \%(194)$ & $\begin{array}{l}34 \% \\
(229)\end{array}$ & $\begin{array}{l}18 \% \\
(120)\end{array}$ & $4 \%(27)$ & 3.3 & 1.1 \\
\hline $\begin{array}{l}\text { I need more help from my } \\
\text { teacher in music lessons }\end{array}$ & $7 \%(50)$ & $22 \%(146)$ & $10 \%(64)$ & $\begin{array}{l}46 \% \\
(309)\end{array}$ & $15 \%(97)$ & 2.6 & 1.2 \\
\hline
\end{tabular}


Table 4: Differences in responses between those not playing an instrument and those reporting playing one or more instruments

\begin{tabular}{|c|c|c|c|c|c|c|c|}
\hline Statement & $\begin{array}{l}\text { Mean } \\
\text { playing an } \\
\text { instrument }\end{array}$ & SD & $\begin{array}{l}\text { Mean non- } \\
\text { instrumenta } \\
\text { lists }\end{array}$ & SD & $\mathrm{F}$ & df & Sig \\
\hline \multicolumn{8}{|l|}{ Concentration } \\
\hline $\begin{array}{l}\text { I concentrate better in music lessons } \\
\text { than other lessons }\end{array}$ & 3.3 & 1.2 & 2.8 & 1.1 & 22.2 & 1,646 & .0001 \\
\hline $\begin{array}{l}\text { Music lessons seem to go more quickly } \\
\text { than other lessons }\end{array}$ & 3.9 & 1.2 & 3.4 & 1.3 & 16.4 & 1,649 & .0001 \\
\hline \multicolumn{8}{|l|}{ Learning and attainment } \\
\hline $\begin{array}{l}\text { The activities we do in music have } \\
\text { helped my to become a better musician }\end{array}$ & 3.9 & .99 & 3.4 & 1.1 & 31.7 & 1,651 & .0001 \\
\hline I have achieved a lot in music lessons & 3.8 & .97 & 2.9 & 1.2 & 81.3 & 1,650 & .0001 \\
\hline $\begin{array}{l}\text { Music lessons have helped me to listen } \\
\text { to music differently }\end{array}$ & 3.4 & 1.2 & 3.0 & 1.3 & 10.3 & 1,649 & .0001 \\
\hline \multicolumn{8}{|l|}{ Teamwork } \\
\hline $\begin{array}{l}\text { I think I work better in music when I } \\
\text { work with my friends }\end{array}$ & 4.2 & 1.1 & 4.3 & .9 & 1.5 & 1,654 & $\mathrm{NS}$ \\
\hline $\begin{array}{l}\text { I have learnt how to work in a group in } \\
\text { music lessons }\end{array}$ & 3.9 & 1.0 & 3.9 & 1.1 & 2.4 & 1,649 & $\mathrm{NS}$ \\
\hline I often help others in music lessons & 3.5 & 1.1 & 2.9 & 1.2 & 29.9 & 1,643 & .0001 \\
\hline \multicolumn{8}{|l|}{ Enthusiasm and interest in music } \\
\hline $\begin{array}{l}\text { I attend music lessons in school } \\
\text { regularly }\end{array}$ & 4.0 & 1.1 & 3.6 & 1.3 & 21.6 & 1,644 & .0001 \\
\hline I enjoy music lessons in school & 4.2 & .78 & 3.7 & 1.1 & 40.4 & 1,654 & .0001 \\
\hline I want to do well in music lessons & 4.4 & .67 & 3.9 & .93 & 67.3 & 1,651 & .0001 \\
\hline \multicolumn{8}{|l|}{ Self-beliefs } \\
\hline $\begin{array}{l}\text { I feel good about myself most of the } \\
\text { time in music lessons }\end{array}$ & 3.9 & .99 & 3.3 & 1.2 & 52.3 & 1,653 & .0001 \\
\hline $\begin{array}{l}\text { I can usually do things as well as most } \\
\text { other people in music lessons }\end{array}$ & 3.9 & .97 & 3.0 & 1.2 & 86.4 & 1,648 & .0001 \\
\hline I feel confident in music lessons & 3.9 & .98 & 3.3 & 1.3 & 47.1 & 1,651 & .0001 \\
\hline I have good musical skills & 3.7 & .98 & 2.5 & 1.2 & 171.2 & 1,650 & .0001 \\
\hline I think I'm a musical person & 3.7 & 1.2 & 2.6 & 1.3 & 99.5 & 1,644 & .0001 \\
\hline \multicolumn{8}{|l|}{ Benefits for other school subjects } \\
\hline $\begin{array}{l}\text { Doing music lessons has helped me in } \\
\text { other school subjects as well }\end{array}$ & 2.8 & 1.2 & 2.4 & 1.2 & 20.5 & 1,652 & .0001 \\
\hline $\begin{array}{l}\text { Doing music lessons has helped me to } \\
\text { feel more positive about school }\end{array}$ & 3.4 & 1.3 & 2.8 & 1.3 & 34.3 & 1,654 & .0001 \\
\hline \multicolumn{8}{|l|}{ Perceptions of teachers and teaching } \\
\hline $\begin{array}{l}\text { My teacher values the music I am } \\
\text { interested in }\end{array}$ & 3.4 & 1.0 & 3.1 & 1.2 & 14.3 & 1,653 & .0001 \\
\hline $\begin{array}{l}\text { I need more help from my teacher in } \\
\text { music lessons }\end{array}$ & 2.5 & 1.1 & 2.9 & 1.3 & 20.1 & 1,651 & .0001 \\
\hline
\end{tabular}

In the focus groups students commented that the time constraints relating to composing a piece of music required considerable concentration: 
'We've learnt how to do things quickly because you don't get many lessons to make those pieces of music. You can't just keep mucking about and starting again. You have to stick with something and keep doing it until it goes right, quite quickly.' (Year 8, boy)

Learning and attainment: The activities engaged with in music lessons were perceived to support the development of musicianship by the majority (72\%) of the participants. Sixty-one percent agreed that they had achieved a lot in music lessons, while 52\% agreed that their listening skills had developed (see Table 3). There were no statistically significant gender differences. However, there were statistically significant differences between those who reported playing one or more instruments and those who did not. Those playing instruments were more positive in relation to all of these statements. The greatest difference in means was in relation to achieving a lot in music lessons, the least in relation to listening to music differently (see Table 4)

In the focus groups the students also reported that participating in Musical Futures had developed their listening skills. This was a recurring theme across all of the year groups, for example:

'My skills have developed. At the beginning of the year, when I listened to a track, when I listened to the piano bit or something, I couldn't just pick up the notes but in this one I'm doing at the moment, they played the track and I sat there and I worked out the beginning of the piece. So it's like really developed my skills for listening.' (Year 9, girl)

Work in developing instrumental skills supported critical listening:

'I used to only listen to the lyrics of songs but now I kind of listen to the instruments and like to see how it works out and I also see like the tone of the singing as well as the tone of the guitar.' (Year 8 , boy) 
Not all of the students were positive about their progress and levels of attainment. One issue that emerged related to the reading of musical notation for those who wanted to continue their musical studies as the Musical Futures approach relies on playing by ear not reading notation:

'I'm learning on my own I don't really know how to read notation and they didn't teach that here at the time, when I first came here, so I think I could have achieved a little more if I'd learned that.' (Year 11 girl)

Overall, there were mixed responses in relation to pupils' perceptions of their musical attainment. Those who played instruments were more positive about their learning and attainment.

Teamwork and peer learning: Eighty-four percent of students believed that they worked better in music lessons when they worked with their friends. This was particularly marked for the girls whose mean score $(4.3, \mathrm{SD}=.97)$ was statistically significantly different from the boys $(4.1, \mathrm{SD}=$ 1.0) $(\mathrm{F}(1,668)=6.7, \mathrm{p}=.009)$. There were no statistically significant differences in responses from those who did or did not play an instrument. Eighty-two percent agreed that they had learnt how to work in a group in music lessons (see Table 3). There were no statistically significant gender differences in response to this statement or between those who did not did not play an instrument. $59 \%$ indicated that they helped others in music lessons. Those who played an instrument agreed more strongly with this statement (see Table 4). This finding was statistically significant. This was also referred to extensively in the interviews. The students reported that Musical Futures provided many opportunities for peer learning. In some cases, students indicated that their peers would know better than teachers what would sound best. This may have been because their teachers were not perceived to be experts in relation to some musical styles. Several students reported that they asked their friends for help with instrumental skills, while those with more developed instrumental skills gained some status in class, as being able to provide help: 
'Working in a group, because if we do something that ain't that good we can improve on it. We'll probably ask somebody else in the class what needs improving and they'll tell us. The [other pupils] know what sounds best.' (Year 9, boy)

'There were people who didn't really know anything and a few of us who knew quite a lot so we told them what chords and stuff.' (Year 10, boy)

The students reported benefits of being able to work with friends:

'I liked that I could work with my friends because we work well together because we knew each other's strengths and weaknesses.' (Year 8 and 9, girl)

However, the students also reported some disadvantages:

'I think the best thing is you get to work with your friends but the worst thing is you're probably going to have a bit of a laugh and waste your time and you don't practise much. You get there in the end.' (Year 8, boy)

Working with friends was not always dispute free:

'I think the good thing is you can be with your mates and if you mess up you can just carry on and get it right next time. The bad thing is you can argue.' (Year 8, boy)

There were sometimes difficulties when people had different levels of expertise, 
'The bad thing is when some people are less advanced than others and you have to wait for them. I wanted to play a different drum beat from the simple one but because of the less advanced people in our group we had to keep everything simple.' (Year 8, boy)

There were also difficulties when everyone in a group was inexperienced:

'My group, we didn't really know what we were doing so we just messed around.' (Year 10, girl)

There were particular challenges when key members of the group were absent:

'Sometimes the people in our group are a bit ill, they don't come into school. It's good when everyone's there but when you're kind of missing key members of the group it kind of falls apart and you can't really do much because you're missing them.' (Year 8, boy)

Overall, the students recognized the complex issues relating to working in friendship groups:

'I think it's good because you get to choose who you work with so you're working with your friends and you get to know them better, it's fun to sit with your friends, and the bad thing is when people don't listen to you it takes forever and it could be really boring because you're just doing nothing, and we had a member of our group that came like half way through the year so we let him in our group because apparently he's a good singer and then he just left without telling us and we were just like, it could go wrong like that.' (Year 9, boy)

There were sometimes clashes over group leadership: 
'The best thing is being able to work with a group and know that you can work with a group well, but the worst thing is that most of them think that they're the boss or they're really good so they should be the best, leader, or something like that.' (Year 8, boy)

Engaging with group work gave students the opportunity to learn transferable skills. Students reported developing strategies for dealing with problems in groups.

'Well when we used to start, when we like went into our classes and we got into groups and then went off, we used to take like half an hour to get ready so we needed to improve on that.' (Year 9, boy)

Students had to learn how to resolve arguments through compromise:

'I think you learn how to deal with a group situation, like if someone isn't necessarily participating as much as someone else, you learn how to deal with that and how to engage them in what you're doing. Like last music lesson we tried to work out the ending of our piece and we had four different ideas and none of us could decide which one, then we worked on it altogether to try and find a way that worked that suited all of us and then we did it in the end because we actually work together well as a group.' (Year 9, girl)

However, there were occasions when teachers had to mediate:

'You mainly sort it out between you but if it gets out of hand someone goes and gets the teacher to sort it out.' (Year 8, boy)

There were times when a breakdown in group work led to a complete lack of a musical output: 
'We've been in groups with these other girls and we ain't friends with them now but we were. We had like a massive fall out and at the end of the project they took the song and all the music so we were stuck with nothing. We were like told off so didn't get our work or level.' (Year 8, girl)

Overall, the students learned about the benefits and difficulties of working in friendship groups and developed team working skills to overcome some of the challenges. They also gained experience of peer learning.

Enthusiasm and interest in music lessons: Seventy-nine percent of the participants indicated that they attended their music lessons regularly. Eighty-nine percent of students indicated that they enjoyed music at school and $90 \%$ that they wanted to do well in music lessons (see Table 3). Responses were more positive for students who played one or more instruments. These differences were statistically significant (see Table 4)

In the focus groups students revealed their enthusiasm for and interest in music. Students indicated that music provided a means of enjoyment and personal expression:

'I got into music in Year 8 and I absolutely loved it. It was my favourite lesson. Year 9 it was [part of] my favourite day.' (Year 9, girl)

'I think it's one of the few ways that you can truly express yourself ... It's a bit mind-blowing actually, it's a huge thing.' (Year 8, boy)

The focus groups provided insights into the ways in which Musical Futures influenced students' enjoyment. For some students it provided a break from more academic classes: 
'Well, if you look at the timetable at the start of the day it's like German, French and then music, it just lightens your entire day, so it gives you something to look forward to.'(Years 8 and 9, boy)

'Sometimes on a day when you don't have any good lessons it's a bit of a drag, school, so when we've got music you think at least I've got a lesson in the day where I can sit with friends and we can actually do something we all like.' (Year 9, boy)

Students described how music was 'fun' and made them 'feel good':

'I think it's just because it's a fun subject and you like stuff more when you're good at it. And because it's a fun subject to do, you want to do well in it because you like it.' (Year 9, boy).

For some students music enhanced attendance because they looked forward to it:

'If I've got music that day, I'll go in and do it because it's nearly one of my favourite lessons.'(Years 8 and 9, boy)

Crucial in relation to enjoyment were the opportunities for practical music making:

'In Year 9 I had [a teacher doing Musical Futures] who's a lot more practical and let us play music and stuff like that so pretty much every lesson we were listening to music or playing it or playing our own music or writing lyrics, which I prefer because I prefer practical. I got to do whatever I wanted.' (Year 10, boy)

Not only was the musical activity practical it gave students freedom to pursue their own musical interests: 
'Basically they tell you you're going to have to make a song, compose it and they just go off and let you do what you want to do. So last year we did the Killers and we're doing it again now, and it was really good because you're free to do whatever you want and you can practise using musical instruments.' (Year 8, boy)

'Something we've been doing in music quite recently actually. In the music tech room we got given a video, well we chose a video and we actually put music to it. You could create your own music out of that. Well, I just enjoyed it really.' (Year 8, boy 8)

Overall, students had a range of reasons for enjoying music but actively making music and choice of music relevant to them were important.

Self-beliefs: In response to the questionnaire, $73 \%$ of students indicated that they felt good about themselves most of the time in music lessons while $67 \%$ indicated that they could usually do things in music as well as most other people. Seventy-three percent said that they felt confident in music lessons, $56 \%$ agreed that they had good musical skills, while $55 \%$ believed that they were a musical person (see Table 3). The girls responded statistically significantly lower than the boys in relation to being confident in music lessons with a mean of $3.6(\mathrm{SD}=1.1)$ as opposed to a mean of $3.8(\mathrm{SD}=1.1)$ $(\mathrm{F}(1,655)=5.9, \mathrm{p}=.015)$. Those who reported playing one or more instruments gave more positive responses to these statements than those who did not (see Table 4).

The focus group interviews provided further insights into the way that students' confidence had developed. Several students indicated that Musical Futures had provided a safe context for them to develop their musical skills enhancing their confidence: 
'I think I've got loads more confidence, I wasn't like a really nervous person when I came to

[School] B, but I don't worry about performing as much. I think I've picked up more confidence and now I can do presentations in other lessons and not be as worried about them.'(Year 9, girl)

'I used to be really shy in music lessons but now I've got more confidence in myself.' (Year 8, boy)

Overall, Musical Futures has the potential to enhance self-beliefs and confidence in participating students. However, some students do not seem to benefit.

To what extent was the Musical Futures approach perceived by students to have benefits in relation to other school subjects?

Only $30 \%$ of students agreed that doing music lessons had helped in other school subjects. Despite this, $51 \%$ agreed that doing music lessons had helped in feeling more positive about school (see Table 3). There were no gender differences in responses, but those playing instruments responded more positively than those not playing instruments (see Table 4).

In the focus groups very few students were able to give examples of how the skills they had developed in music transferred to other areas of school work. Group work was the most common example:

'Group work especially, collaborating with one another, it helps in other lessons, PE, science even, getting into groups making charts of your own experiments. It's all about communication to each other and once you learn that it makes the world seem easier and it makes talking to everyone easier.' (Year 8, boy) 
'Well, something that helped me in other lessons would be team work. We've had to work in groups quite a lot and I'm not actually that good at team work because I like having my own way quite a lot.' (Year 8 , boy)

Related to this was placing less reliance on teachers:

'It's quite a big thing I've learnt from music. I was always quite dependent on what the teacher thought because they knew more about it than I did. I didn't have a clue what I was doing! So it was always is that $\mathrm{OK}$, is that right, is that OK? But now I've kind of gone away from that a bit which has really helped and that's helped in other lessons as well' (Year 8, boy).

Another example related to the use of computers in more than one subject:

'When we're using the MACs that helps us in art because we use MACs in art as well.' (Year 7, boy)

One student described how she used rhythm and songs to help to solve problems in maths:

'It's to help your rhythm. Just that really. It's good for other subjects, maths or English and you have to work out the, in maths if you have to work out something you can do it in a song you can remember it easier.' (Year 8 , girl)

Some students reported improvement in concentration which transferred to other subjects:

'I've got better at being able to concentrate which helps me in other subjects like science.' (Year 8, girl) 
Overall, most students did not perceive that engagement with Musical Futures was impacting on their school work more generally.

\section{How did students participating in Musical Futures perceive their teachers and their teaching?}

Despite being involved in Musical Futures only $43 \%$ of participants agreed that their teacher valued the music that they were interested in (see Table 3). Those reporting playing instruments gave more positive responses to this statement (see Table 4). This difference was statistically significant. Twenty-nine percent indicated that they needed more help from their teacher in music lessons (see Table 3). Those not playing instruments more strongly agreed with this statement (see Table 4). This difference was statistically significant.

Teacher support and feedback: In the focus groups students demonstrated that their teachers had very different ways of implementing the Musical Futures approach particularly in relation to the role that they played in giving constructive feedback. Musical Futures seemed to have changed some teachers' approach from their previous practice:

'... Help from a teacher, he did help but it was just little, not like he would now. Now he'd come in and say show me what you've done and it's out of time or something.' (Year 10, boy)

The students appreciated comments that helped them improve and get better marks:

'I get feedback about how it's good and then how I can improve. It's more helpful than just saying it's good.'(Year 10, boy)

'We played it at a different time [i.e. individually] and were told what was good and what we needed to improve on.' (Year 9, girl) 
In some instances, pupils perceived that they were receiving no feedback which would help them to improve:

'He comes round and sees how we're doing but he doesn't tell us, if I play the piano to him he'll say it's good but he won't explain how I can improve it so I don't know what I can do to get a higher mark.' (Year 10, girl)

Some students wanted more formative feedback:

'More feedback and also structure from the teachers as well, like, because at the end of the unit you get told your target and level. You don't get told what you've done well and what you haven't done well. You don't really get any personal feedback while you're doing it. We could improve, if we got feedback nearly half way through so we could always improve it and like raise our level.'(Year 9, girl)

In the focus groups some students indicated that teachers were not equitable in the time spent with each group. There was frustration from some students who perceived that their teacher favoured the strongest students:

'Lower down the years, they involve you but they've always favoured the kids who've been good at music.' (Year 11, boy).

However, some perceived that their teacher spent more time with the weakest students:

'People who obviously didn't have the music lessons and don't understand much need lots of help, like reading music' (Year 10, boy). 
It was clear from the focus group interviews that the students liked receiving help but only when they needed it:

'They help us. But like if we need the help. We go off in our groups and then the teacher will come in and say how are you doing and if we're struggling she'll come and help us.'(Year 8, girl)

Some students complained about the length of time they had to wait to get support:

'Sometimes you have to wait ages until you can get on with your work.' (Year 8, girl)

They were appreciative when help came quickly:

'The teacher we've got now she's really nice and like she helps us with everything like really quickly.'(Year 9. boy)

The level of support that students needed from teachers depended on their level of musical expertise. For those students who already played instruments independent work was feasible and welcomed, for those with less experience there were issues about the level of support that the teacher could offer.

Teacher enthusiasm: Most students appreciated their teacher's enthusiasm:

'I think teachers who are enthusiastic about teaching make their students enthusiastic 'cos if you can see you teacher's really into it and like dancing about and singing really loudly then you think oh this is really fun, and she's not afraid to make a fool out of herself so we shouldn't sit back and 
look on and not do anything, we should go out there and do what we want to do.'(Years 8 and 9, boy)

Not everyone agreed that the teacher needed to be enthusiastic:

'Most of the thing with Musical Futures is it is independent learning so most of the time you are on your own and the only thing you really need the teacher for is tuning up and possibly a bit of advice every now and then on which direction to go before you do it. So if you have a teacher that's really enthusiastic I suppose, that would help but to be honest I don't think it really matters much.' (Year 9, boy)

Overall, students recognize that teacher enthusiasm contributes to their interest in music.

Autonomy: Closely related to the role of the teacher in Musical Futures was students' stress on the importance of autonomy. This was in part being able to choose what music to learn:

'I really like being able to play and not having the teacher saying that's what you're going to play but go out and find your own music and then go in groups and play it and have an accompaniment with it, playing the instrument you want.' (Year 8, girl)

'I like what we're doing at the moment in music which is making our own songs, writing our own lyrics. It's really fun because you get to have the freedom to write what you want.' (Year 7, boy)

Students valued the opportunity to be independent learners, for example:

'I suppose it depends really on who you are. If you are quite a musical person and you enjoy it then you put the effort in, you don't really need any help from the teacher.' (Year 9, boy) 
Others emphasized learning skills themselves:

'It's quite good that you get the freedom to make up your own, because we've been making up songs and the teacher doesn't help you which is good because you learn a lot of skills by yourself so.' (Year 9, girl)

Others compared Musical Futures with previous music teaching in their school:

'I liked making our own song because we had to totally think of new lyrics and think of it just ourselves and then perform it in front of people who came from different schools. And I didn't like, music lessons in year 7. We just used to play on the keyboards every lesson and it was really boring.' (Boy year 9)

Allowing this level of independence required considerable trust on the part of the teacher:

'I think the students are given a lot of trust from the teachers. We have quite a lot of freedom to do what we want. Because we're given that trust, the majority of us do well, and we do behave but there's always going to be some that don't because there always is.' (Year 9, boy)

For most students, the sense of autonomy that they had and the way that they could choose the music that they learned was important in sustaining their interest.

The role of performance: The opportunities for performance played an important role in the learning experience. Having to perform in front of peers provided opportunities for positive feedback which was motivating: 
'When you get into a band it's nice and fun, and then you come to show your classmates and then you go into the next lesson and the classmates are saying oh nice song and stuff, and then even when you do a solo and stuff, when you perform, it's a good atmosphere.' (Year 8, boy) 'I remember we had to compose our own song and I was very happy that I got to perform it and everyone really liked it and they clapped it. It just like, it makes you feel really happy that people actually like your work.' (Year 10, girl)

Another emerging issue related to the students' perceptions of their performance which they sometimes found disappointing:

'I enjoy it when people bring their CDs, listening to their music and playing music because I like listening to people's taste in music. I didn't enjoy recording it because sometimes when we recorded it, it was out of tune and stuff like that.' (Year 7, boy)

There was also a perception that the students shared the same anxieties and concerns about performance:

'Well I think that it kind of feels in music lessons that everyone's in the same boat like when we go up to perform everyone's kind of like you know nervous about it and everyone's going to have their turn so it seems fair on anyone if you get me.' (Year 10, boy)

It was clear that the performance of what had been learned or composed played an important role in the informal learning process.

\section{Discussion}


The evidence from this research showed that, overall, where the Musical Futures approach was being implemented, most students enjoyed their music lessons. This supports the international literature on the introduction of informal learning of popular music into the school curriculum (see Karlsen \& Vakeva, 2012). Evidence from the Nordic countries, despite the criticisms made of lessons being based on popular music, showed that most students enjoyed music lessons (Skolverket, 2004). In the focus groups the main reasons that students gave for enjoying lessons was the independence that they were given, being able to work with friends and being able to choose the music that they worked on. However, some students did not enjoy music lessons nor did they want to achieve in music reflecting the findings from the Nordic research. There may have been many reasons for this; their musical preferences may not have been met, they may have found working in a group difficult or they may have found performing to their peers extremely anxiety provoking. Of course, enjoyment of lessons is not the main aim in most school subjects; the key aim is that students should learn. Should music be an exception to this? There is an argument that the wide benefits which active music making can offer in terms of well-being and health throughout the lifespan (see Hallam, 2015) are such that music in schools should aim to develop a love of music so that students continue to engage with music when they no longer take it as a school subject. However, music should also be valued for its own sake with a similar focus on learning and attainment as in other subjects. In fact, these two aims are not mutually exclusive. Having a sense of achievement makes a major contribution to enjoyment enhancing motivation (Creech et al., 2014).

Although most students reported enjoying music their responses relating to some elements of learning were less positive. Most did not report greater concentration in music lessons than other lessons, although a greater number indicated that music lessons seemed to go more quickly. Losing track of the passage of time is one of the characteristics of being in a state of 'flow', an optimal state for learning (Csikszentmihalyi, 1990) suggesting that the environment created within the Musical Futures approach was indeed promoting learning. Despite this, a substantial proportion of the students reported in the questionnaires that the activities were not helping them to become better 
musicians nor that there had been an impact on the way that they listened to music. Given these responses, it is not surprising that only $55 \%$ indicated that they thought that they were a musical person. This suggests that while the Musical Futures approach had enhanced interest for a substantial proportion of students, many had failed to develop an identity as a musician, a crucial factor in maintaining engagement with music throughout the lifespan (Hallam et al., 2015). This reflects the evidence from the Nordic research which reported that some students' needs were not being met (Bergman, 2009). In addition, the majority of students disagreed that their teachers valued the music that they were interested in suggesting that despite the adoption of the Musical Futures approach there is still a disconnect between music in school and that in young people's lives outside school. There was also some indication that some teachers favoured students who already played instruments and had well developed musical skills. This supports the findings from Oftsted (2009).

One positive outcome of the adoption of the Musical Futures approach related to teamwork and peer learning with most students indicating that their team-working skills had improved. The girls were more positive than the boys about working with their friends. This may be because girls prefer to work in co-operative, supportive working environments whereas boys work well in competitive, pressurised environments (Boaler, 1997a, b \& c). There were no statistically significant differences in relation to responses about team working between those who already played a musical instrument and those who did not. The experience of working independently in a small group seemed to be of benefit to all of the students. A smaller proportion indicated that they helped others in music lessons reflecting the extent to which individual students had sufficient musical skills to offer support to others. Those who played at least one instrument engaged in more supporting activities. Working with others was not always a positive experience and when relationships broke down or students were frequently absent musical outcomes were negatively affected. It would seem that students would benefit from being provided with guidance and support about how to work in a team as part of their induction into the Musical Futures approach. 
In the focus group interviews, students reported that they valued the autonomy that the approach gave them. However, in responses to the questionnaire almost $30 \%$ indicated that they needed more support from the teacher. When adopting work-shopping approaches to teaching, such as the Musical Futures approach, teachers find it difficult to support all of the students and they can find it exhausting (Hallam et al., in press b). This is a major challenge for the approach. While it could be solved by reducing class sizes or increasing the number of teachers or teaching assistants, in the current economic climate this is not likely to be a viable option.

The kind of support that students indicated that they needed generally related to formative assessment. This shows considerable insight as being given detailed feedback on how to improve is crucial to learning (Black and Wiliam, 1998). The Musical Futures approach was reported by teachers as making the assessment of students' work and progress easier as the focus on small group work and performance enabled them to hear the contribution of each student thereby facilitating the giving of detailed formative assessment (Hallam et al., in press b). This is a positive outcome of the adoption of the approach particularly given that Ofsted (2009) suggested that such procedures were not generally embedded in secondary class music lessons.

The majority of students in the sample reported playing at least one instrument. The findings supported earlier research which showed that those playing instruments tended to value music more and have more positive music related self-beliefs than those not playing instruments (Eccles \& Wigfield, 2002; McPherson \& O'Neill, 2010). In contrast to the earlier research, the girls in this study had lower levels of confidence in music lessons than the boys. This may be related to the type of music making being undertaken which mainly focused on 'pop' bands. Boys have been demonstrated to be more interested in music when it involves technology and electronic instruments, a particular focus of much of the early Musical Futures work (Comber, Hargreaves \& 
Colley, 1993; Green, 1997; Hanley, 1998). Overall, the findings indicated that playing an instrument enhanced the students' experience of music in the classroom.

Generally, the participants did not report any benefits of participating in Musical Futures for other school subjects. This does not necessarily mean that there were no benefits, just that the students may not have been aware of them. In fact, the evidence from non-music teachers and members of the senior management teams of the schools indicated a wide range of benefits (Hallam et al., in press, c). 'There was greater agreement among participants that music lessons helped them to feel more positive about school. This may be because in music lessons they engaged in practical activities, although it may also indicate that they were benefitting from the power that music has to change mood and impact on the emotions (Juslin, 2009).

Of course there are limitations to this research. The statements in the questionnaire were all worded positively to facilitate student understanding. This may have biased the findings. In addition, the research was undertaken in Musical Futures Champion schools, where the approach was well supported by senior managers and the great majority of music staff. The findings may not have been so positive had the research been undertaken in schools were staff were less engaged. This is likely to have limited the generalisability of the findings.

\section{Implications for education}

Students clearly value and enjoy practical music making, working in groups and having a degree of choice and autonomy in the activities that they undertake. Those with expertise in playing a musical instrument were more positive in their responses to the Musical Futures approach and were clearly at an advantage. Currently in the UK, children in primary schools participate in a programme called First Access in which they all learn to play a musical instrument free of charge for a period of time (this varies between different implementations of the programme). The primary music curriculum 
also requires children to learn to read musical notation. If these opportunities could be sustained throughout the primary years, many of the challenges of informal learning at secondary school would be addressed and the many benefits which can accrue from active engagement with music would be realized (Hallam, 2015). For such a music curriculum to be implemented primary head teachers would need to be committed to music and prepared to finance the initiative. If this proves to be impractical instrumental skills could be introduced into class music lessons in the first years of secondary school, a practice which some Musical Futures schools have already adopted.

\section{References}

Altrichter, H., Feldman, A., Posch, P. \& Somekh, B. (2008). Teachers investigate their work; An introduction to action research across the professions. Routledge. (2nd edition).

Benson, F. (2012) Thrown in at the deep end: Informal learning in a primary music classroom. Unpublished undergraduate thesis, Sydney Conservatorium of Music, University of Sydney.

Bergman, A. (2009) Vaxa upp med music: ungdomars musikanvandande i skolan och pa fritiden (Growing up with music. Young people's use of music in school and during lesson time. Phd Dissertation, University of Gothenburg.

Black, P., and Wiliam, D. (1998) 'Inside the black box: Raising standards through classroom assessment'. Phi Delta Kappan, 80(2): 139-149

Boaler, J. (1997a) 'Setting, social class and survival of the quickest'. British Educational Research Journal, 23, 575-595. 
Boaler, J. (1997b) 'When even the winners are losers: evaluating the experiences of 'top set' students'. Journal of Curriculum Studies, 29, 2, 165-182.

Boaler, J. (1997c) 'Reclaiming school mathematics: The girls fight back'. Gender and Education, 9, 3, 285-306.

Bouchard, T.J., Jr. 1976 "Unobtrusive measures: An inventory of uses." Sociological Methods and Research, 4: 267-300.

Bray, D. (2000) ‘An examination of GCSE music uptake rates'. British Journal of Music Education, 17(1), 79-89.

Button, S. (2006) 'Key Stage 3 pupils' perception of music'. Music Education Research, 8(3), 417431.

Clark, A. \& Moss, P. (2001) Listening to young children: The mosaic approach. London: National Children's Bureau

Comber, C., Hargreaves, D.J. \& Colley, A. (1993). Girls, boys, and technology in music education, British Journal of Music Education. 10, 123-34.

Creech, A., Hallam, S., McQueen, H., \& Varvarigou, M. (2014). Active ageing with music: Supporting well being in the Third and Fourth Ages. London: IOE Press.

Csikszentmihalyi, M. (1990). Flow: The Psychology of Optimal Experience. Harper \& Row. 
D’Amore, A. (2014) Ten Years of Musical Futures: Take, Use, Innovate, Share. London: Paul Hamlyn Foundation

Eccles, J. E., O’Neill, S. A., \& Wigfield, A. (2005). Ability self-perceptions and subjective task values in adolescents and children. In K. A. Moore \& L. H. Lippman (Eds.), What do children need to flourish? Conceptualizing and measuring indicators of positive development (pp. 237-249). New York: Springer.

Eccles, J. S., \& Wigfield, A. (2002). Motivational beliefs, values, and goals. Annual Review of Psychology, 53, 109-132.

Evans, S.E., Beauchamp, G., \& John, V. (2015) Learners' experience and perceptions of informal learning in Key Stage 3 music: a collective case study, exploring the implementation of Musical Futures in three secondary schools in Wales, Music Education Research, 17(1), 1-16.

Finney, J \& Philpott, C. (2010) Informal learning and meta-pedagogy in initial teacher education in England, British Journal of Music Education, 27(1), 7-19.

Ghazali, G., \& McPherson, G. E. (2009). Malaysian children's attitudes toward learning music.

Music Education Research, 11(2), 193-219.

Green, L. (1997). Music, gender and education. NY: Cambridge University Press

Green, L. (2002) How Popular Musicians Learn: A Way Ahead for Music Education. Aldershot: Ashgate Publishing Ltd. 
Green, L. (2008) Music, Informal Learning and the School: A New Classroom Pedagogy. Aldershot, Ashgate Publishing Ltd.

Hallam, S. (2015) The power of music: A research synthesis of the impact of actively making music on the intellectual, social and personal development of children and young people. London: iMERC

Hallam, S., Creech, A and McQueen, H. (2009) Musical Futures: A case study investigation, an interim report from the Institute of Education, University of London for the Paul Hamlyn Foundation. London: Institute of Education.

Hallam, S., Creech, A. \& McQueen, H. (in press a). Teachers' perceptions of the impact on students of the Musical Futures approach, Music Education Research.

Hallam, S., Creech, A \& McQueen, H. (in press b) What impact does teaching music informally in the classroom have on teachers, and their pedagogy? Music Education Research.

Hallam, S., Creech, A., \& McQueen, H. (in press c) The perceptions of non music staff and senior management of the impact of the implementation of the Musical Futures approach on the whole school, British Journal of Music Education.

Hallam, S., Creech, A., Papageorgi, I., Gomes, T., Rinta, T. Varvarigou, M., Lanipekun, J. (2015) Changes in motivation as expertise develops: relationships with musical aspirations. Paper presented at the $9^{\text {th }}$ Trennial Conference of the European Soceity of the Cognitive Sciences of Music, $17^{\text {th }}-22^{\text {nd }}$ August, Royal Northern College of Music, Manchester, UK. 
Hallam, S., Creech, A., Sandford, C., Rinta, T. and Shave, K. (2008) Survey of Musical Futures: A report from Institute of Education, University of London for the Paul Hamlyn Foundation. London: Institute of Education, University of London

Hanley, B. (1998). Gender in secondary music education in British Columbia. British Journal of Music Education, 15(1), 51-6.

Jeanneret, N., (2010) Musical Futures in Victoria. Australian Journal of Music Education. 2.

Jeanneret, N., McLennan, R., \& Stevens-Ballenger, J. (2011) Musical Futures: An Australian PerspectiveFindings from a Victorian Pilot study. Melbourne Graduate School of Education, Melbourne University.

John, V \& Evans, S. (2013) Musical Futures: Summary of the Findings of the Wales Pilot 20112012. Doi. hpps://www.musicalfutures.org/resource/27964/title/musicalfutureswalespilot201112. Accessed 14-01-15

Juslin, P. (2009). Emotional responses to music. In S.Hallam. I. Cross \& M. Thaut. (eds) The Oxford Handbook of Music Psychology. Oxford: Oxford University Press (pp131-140)

Karslen, S. \& Vakeva, L (eds) (2012) Future prospects for music education: Corroborating informal learning pedagogy. Newcastle on Tyne, UK: Cambridge Scholars Publishing.

Musical Futures (2014) www.musicalfutures.org.uk Accessed 20-07-15

Lamont, A., Hargreaves, D.J., Marshall, N.A., and Tarrant, M. (2003) 'Young people's music in and out of school', British Journal of Music Education, 20(3), 229-241. 
Lincoln, Y. S., \& Guba, E. G. (1985). Naturalistic inquiry. Beverly Hills, CA: Sage.

Little, F. (2009) 'An Exploration into the Uptake Rates of GCSE Music with a Focus on the Purposes of Music in School'. Unpublished EdD thesis, University of Durham.

McPherson, G.E. (2007, 6-10 July). Children's motivaton to study music in schools. In R. Faulkner, A. Stanberg, \& J. MacIntosh (Eds.), Proceedings of the Australian Society for Music Education Biennial National Conference [CD-ROM]. Perth, Western Australia.

McPherson, G.E. \& O’Neill, S.A. (2010) Students' motivation to study music as compared to other school subjects: A comparison of eight countries. Research Studies in Education, 32(2), 101-137

McQueen, H. \& Hallam, S. (2010) Music in the secondary school. In S. Hallam \& A. Creech (eds) Music Education in the $21^{\text {st }}$ Century in the United Kingdom: Achievements, analysis and aspirations. London: Institute of Education, University of London.

Ofsted (2006) An Evaluation of the Paul Hamlyn Foundation's Musical Futures Project (HMI 2682). London: Ofsted.

Ofsted (2009) Making more of music: An evaluation of music in schools 2005/2008. London: HMSO.

O’Neill, S. A. (2006). Positive youth musical engagement. In G. McPherson (Ed.). The child as musician: A handbook of musical development (pp. 461-474). Oxford: Oxford University Press. 
O’Neill, S \& Bespflug, K. (2011) Musical Futures Comes to Canada: Engaging Students in RealWorld Music Learning, Canadian Music Educator/ Musicien Educateur au Canada, 53(2), 25.

Patton, M. Q. (2002). Qualitative evaluation and research methods (3rd ed.). Thousand Oaks, CA: Sage Publications, Inc.

Pitts, S. (2005). Valuing musical participation. Aldershot: Ashgate

Skolverket (Swedish National Agency for Education) (2004) Nationell utvardering av grundskolan 2003. Bild, him-och konsumentkunskap, idrott och halsa, music och slojd (National Evaluation of the Compulsory School in 2003. Subject Report. http://www.skolverket.se/publikationer?id=1385

United Nations (1989) Convention for the rights of the child. New York: United Nations

United Nations (2005) Convention on the rights of the child: General Comment No

7..Implementing child rights in early childhood. Geneva: United Nations

Wright, R. (2002) 'Music for all? Pupils perceptions of the GCSE music examination in one South Wales secondary school', British Journal of Music Education, 19(3), 227-241.

Younker, B.A., Wright, R., Linton, L., \& Beynon, C. (2012). "Tuning into the Future: Sharing Initial Insights about the 2012 Musical Futures Pilot Project in Ontario"Canadian Music Educator 53.4 (2012): 14-18. 